\title{
An Appraisal of Nigeria's Membership and Participation in the World Trade Organisation (WTO)
}

\author{
Umar AbubakarDubagari* \\ Faculty of Law, UsmanuDanfodiyo University, Sokoto - Nigeria \\ GSM 23408131626080
}

\begin{abstract}
The World Trade Organisation(WTO) is responsible for global rules of trade between nations in order to enhance free movement of goods and services, in the belief that it will be beneficial for all parties involved. Like other developing countries, Nigeria is left with no option than to accept the rules of the WTO that were detrimental to its interest. However, it accepted the existing rules and continues to insist that the unfavourable ones be reformulated to take account of its interest and call for the creation of a most favourable international economic order.Nigeria's participation in the WTO is to reaffirm its commitment to trade liberalisationand to seek technical support of the international community for more beneficial integration of its economy into the global trading system. In doing so, it has promulgated series of economic policies for the purposes of facilitating the achievement of rapid economic development but with little or no significant result.
\end{abstract}

Keywords: World Trade Organisation, Membership, Participation, Economic Integration, Nigeria

\section{INTRODUCTION}

The World economic order was re-established in 1947 (after the Second World War) under the banner of the Bretton-Woods Institutions, ${ }^{1}$ in-order to promote the integration of national economies. ${ }^{2}$ This was reinforced by the economic downturn of the 1970s and 1980s which both developed and developing countries (Nigeria inclusive) were adversely affected. These countries therefore adopted economic reform policiesprescribed by international financial institutions, ${ }^{3}$ undoubtedly believed to be the only road map towards economic recovery and national development. ${ }^{4}$ The World Trade Organisation (WTO) which replaces the General Agreement on Tariffs and Trade (GATT) ${ }^{5}$ as a United Nations (UN) specialised agency was saddled with the responsibility of global rules of trade between nations. ${ }^{6}$

Although this economic integration was designed to enhance free trade of goods and services, in the best interest of all parties, ${ }^{7}$ it may be easier for a small group of neighboring countries with similar concerns and cultures to agree on market opening in a particular area than to reach agreement in a wider forum such as the WTO. On the other hand, it makes it harder for countries outside the region to trade with those inside. But

\footnotetext{
${ }^{1}$ This includes the International Monetary Fund (IMF), the World Bank, Paris Club and other Creditor Nations.

${ }^{2}$ Bossche, P. V. The Law and Policy of World Trade Organisation, Texts, Cases and Materials, (Cambridge University Press, New York, 2005), p. 3.

${ }^{3}$ The IMF and the World Bank compelled developing countries to adopt and implement policies such as Structural Adjustment Programmes (SAP), liberalisation and deregulation of the key sector of the economy, privatisation and commercialisation of state financial and economic institutions.

${ }^{4}$ Agada, J, Gathegi, J, Britz, J and Lor, P, "Globalisation of Intellectual Property Rights: Implications of the TRIPS Agreement for Access to HIV/AIDS Drugs in Africa", available at $<$ http://www.asis.org/Conferences/AM09/open-proceedings/panels/49.xml>.Accessed on 18/10/13.

${ }^{5}$ The legalism embedded in GATT was found to be imperfect due to institutional defects. For instance, prior to the WTO, a country could choose which of the Codes (GATT), if any, it would implement and this created different rights and obligations, even a country which did not implement a Code could nevertheless benefit from it. The GATT of 1947 continued until the end of 1995, when it was effectively subsumed, with changes as GATT 1994 within the WTO system.

${ }^{6}$ World Trade Organisation, "Becoming a Member of the WTO", available at<http://www.wto.org/english/thewto_e/minist_e/min99_e/english/about_e/21accs_e.htm>.Accessed on 15/06/14.

7Shah, A., "Some Regional Trade Agreements", available at <http://www.globalissues.org/article/44/someregional-free-trade-agreements $>$.Accessed on 15/11/13. 
multilateral negotiations, with more players and more sectors will offer greater potential for mutual gains than limited bilateral or regional deals. ${ }^{8}$

However, this business-driven integration of the global economy has been a matter of great concern to Nigeria. It reduces the sovereign ability of government to take decisions. It is also considered as an international economic system where the developed countries, which are technologically advanced, are the producers of a greater part of industrial and consumer goods manufactured and exported annually, while developing countries remain importers and consumers. ${ }^{9}$

Critical about the economic order, Bhaja observes that:

The global trading system is dominated by a few hegemonic trading powers... This minority tends to be far more interested in gaining market access to or shutting imports out from developing countries than in promoting export-oriented growth in those countries. The powers preach free trade until they come to the negotiating table with developing countries when they become mercantilists. ${ }^{10}$

With the current global trading climate, therefore, to what extent has Nigeria's membership and participation in the WTO impacted on its economy? In answering this question, this paper unravels the historical structure of the WTO. It examines Nigeria's membership and participation in the WTO and influence of the WTO agreements on Nigeria's economy. It also discusses Nigeria and the regional economic integration systems, as well as the implementation challenges of the WTO agreements and concludes by making observations and proffering recommendations.

\section{HISTORICAL STRUCTURE OF THE WTO}

The WTOwas established on January 1, 1995 as a result of the Uruguay Round of trade negotiations that commenced in 1986 and concluded with signing of complex agreement at Marrakesh, Morocco on 15 April 1994. The agreement covers a wide range of economic issues, such as agriculture, textiles and clothing, rules of origin, import licensing procedures, subsidies, intellectual property rights and etc. ${ }^{11}$

The main function of the WTO is to ensure that trade flows as smoothly, predictably and freely as possible. ${ }^{12}$ The reason for the establishment of the WTO and the policy objectives are set out in the Preamble to its Agreement. According to the preamble, the parties to the WTO Agreement agreed to the terms of the Agreement and the establishment of the WTO. It states that:

Recognising that their relations in the field of trade and economic endeavour should be conducted with a view to raising standard of living, ensuring full employment and a large and steadily growing volume of real income and effective demand, and expanding the production of and trade in goods and services, while allowing for the optimal use of the world resources in accordance with objectives of sustainable development, seeking both to protect and preserve the environment and to enhance the means for doing so in a manner consistent with their respective needs and concerns at different levels of economic development... ${ }^{13}$

The WTO's Secretariat headed by a Director-General is based in Geneva, Switzerland. Decisions are taken by the members themselves; the Secretariat does not have the decision-making role like other international bureaucracies. The Secretariat's main duties are to supply technical support for the various councils and committees and the ministerial conferences, provide technical assistance for developing countries, analyse world trade, and explain WTO affairs to the public and media. The Secretariat also provides some forms of legal assistance in the dispute settlement process and advises governments wishing to become members of the WTO. ${ }^{14}$

The WTO's top level decision-making body is the Ministerial Conference, consisting of representatives of all members meeting at least once every two years and exercising the functions of the Conference between sessions. ${ }^{15}$ It is clear that it is impossible to negotiate effectively with such a large number of memberships. But mechanisms have been developed to reduce the number of countries actively participating in the deliberations so

\footnotetext{
${ }^{8}$ Ibid.

${ }^{9}$ Ayodele, A., "Globalisation, the TRIPS Agreement and their Implications on Access to Essential Medicine for Developing Countries: A Case Study of Nigeria", Vol. 2, part 1,Confluence Journal of Private and Property Law (CJPPL), (2009), p. 102.

${ }^{10}$ Bhaja, R., "Challenges of Poverty and Islam Facing American Trade Law", Vol. 17,St John's Journal of Legal Commentary, (2003), p. 471.

${ }^{11}$ Shaw, M. N., International Law, $\left(4^{\text {th }}\right.$ Edition), Grotius Press Ltd., Cambridge, (1997), p. 893.

${ }^{12}$ World Trade Organisation, op cit.

${ }^{13}$ See Preamble to the WTO Agreement.

${ }^{14}$ WTO, "The WTO in Brief; Part 2", available

at<http://www.wto.org/english/thewto_e/whatis_e/inbrief_e/inbr02_e.htm>. Accessed on 01/10/13.

${ }^{15}$ Ladan, M T, opcit, p 893. 
as to allow the WTO come to decisions. One of such mechanisms is the 'green room' meetings. ${ }^{16}$ This mechanism brings the major trading powers and a selected group of developing countries members together in order to reach preliminary agreements which are then presented to the rest of the members, and to allow all interested members to make their views known in such consultations, etc. ${ }^{17}$

Below the Ministerial Conference is the General Council (usually ambassadors and heads of delegation in Geneva, but sometimes officials sent from members' capitals) which meets several times a year in the Geneva headquarters. The General Council also meets as the Trade Policy Review Body and the Dispute Settlement Body (DSB). Below the General Council are Councils for Trade on Goods, Trade in Services and Trade related aspects of intellectual property rights operating under the general guidance of the General Council. ${ }^{18}$ There are also numerous specialized committees, working groups and working parties dealing with the individual agreements and other areas such as the environment, development, membership applications and regional trade agreements. $^{19}$

However, the establishment of the WTO as a specialised agency of the UNwith international personality results in the formation of a new legal person, separate and distinct from that of the states that created it. This separate and distinct personality necessarily imports consequences as to international responsibility, both to and by the organisation. ${ }^{20}$ The WTO enjoys privileges and immunities for its assets, properties and representatives similar to other specialised agencies of the UN. ${ }^{21}$ But, this does not make it equal to states, nor does it make its rights and duties the same as those of states. ${ }^{22}$

Subject to few exceptions granted in favour of developing countries and least developed countries, ${ }^{23} \mathrm{due}$ to their level of economic development, every WTO member is obliged to conform to the terms and conditions of the agreement.Although it is not possible to comment on all the agreements annexed to the WTO treaty, a few of the innovations are hereby selected for consideration.

\section{i. Trade Related Investment Measures (TRIMS)}

This Agreement, negotiated during the Uruguay Round, applies only to measures that affect trade in goods. Recognising that certain investment measures can have trade-restrictive and distorting effects, it states that no member shall apply a measure that is prohibited by the provisions of GATT Article III (national treatment) or Article XI (quantitative restrictions). Examples of inconsistent measures, as spelled out in the Annex's Illustrative List, include local content or trade balancing requirements. The Agreement also establishes a Committee on TRIMs to monitor the operation and implementation of these commitments. ${ }^{24}$

\section{ii. Trade Related Aspects of Intellectual Property Rights (TRIPS)}

The TRIPS agreement introduced intellectual property law into the international trading system for the first time and remains the most comprehensive international agreement on intellectual property to date. Specifically, TRIPS requires WTO members to provide copyright rights, including performers, producers of sound recordings and broadcasting organizations; geographical indications, including appellations of origin; industrial designs; integrated circuit layout-designs; patents; new plant varieties; trademarks; trade dress; and undisclosed or confidential information. TRIPS also specify enforcement procedures, remedies, and dispute resolution procedures. Protection and enforcement of all intellectual property rights shall meet the objectives to contribute to the promotion of technological innovation and to the transfer and dissemination of technology, to the mutual advantage of producers and users of technological knowledge and in a manner conducive to social and economic welfare, and to a balance of rights and obligations. ${ }^{25}$

\footnotetext{
${ }^{16}$ It was named after a conference room next to the office of the Director-General, where contentious issues are often hotly debated. This 'green room' meeting brings together about twenty or more deliberations at the invitation of the Director-General.

${ }^{17}$ Bossche, P. V., op cit, pp. $151-153$.

${ }^{18}$ Article IV of the WTO Agreement.

${ }^{19}$ WTO, op cit.

${ }^{20}$ See ICJ Reports, 1949, pp. 174 and 183.

${ }^{21}$ Sheater, I.A, Starke's International Law, (4th Edition), Butterworths, London, (1994), p. 559.See also Article 105 (1) and (2) of the UN Charter, the Convention on the Privileges and Immunities of the UN 1946 and the Convention on Privileges and Immunities of the Specialized Agencies 1947. See Also Section 9 (1) of the Diplomatic Immunities and Privileges Act 1961 (as amended) and Article viii of the Marrakesh Agreement.

${ }^{22}$ Ladan, M T, op cit, p. 33.

${ }^{23}$ Articles 66 (2) and 67 of the WTO Agreement.

${ }^{24}$ Ladan, M T, op cit, p. 353 "

${ }^{25}$ Ibid., p. 354 
While the actual TRIPS agreement does not define safeguards, a number of provisions have become known as TRIPS public health safeguards because they enhance the affordability and availability of medicines. These safeguards include: compulsory licensing, extension of the transition period for the enforcement of intellectual property rights, parallel imports, and pool/bulk procurement, ${ }^{26}$ allowing generic drugs producers to prepare production and obtain regulatory approval for generic versions of patent medicines before the patent expires (Bolar provision). ${ }^{27}$

\section{iii. Import Licensing Procedures}

The Agreement on Import Licensing Procedures says import licensing should be simple, transparent and predictable so as not to become an obstacle to trade. For instance, the agreement requires governments to publish sufficient information for traders to know how and why the licences are granted. It also describes how countries should notify the WTO when they introduce new import licensing procedures or change existing procedures. Work on this subject is handled by the Committee on Import Licensing. ${ }^{28}$

\section{iv. General Agreement on Tariffs and Trade (GATT)}

This is a multilateral agreement regulating international trade. According to its preamble, its purpose was the "substantial reduction of tariffs and other trade barriers and the elimination of preferences, on a reciprocal and mutually advantageous basis." Whilst GATT was a set of rules agreed upon by nations, the WTO is an institutional body. The WTO expanded its scope from traded goods to include trade within the service sector and intellectual property rights. Although it was designed to serve multilateral agreements, during several rounds of GATT negotiations (particularly the Tokyo Round) plurilateral agreements created selective trading and caused fragmentation among members. ${ }^{29}$

\section{v. General Agreement on Trade in Services (GATS)}

The objectives of GATS was to create a credible and reliable system of international trade rules, ensuring fair and equitable treatment of all participants (principle of non-discrimination), stimulating economic activity through guaranteed policy bindings, and promoting trade and development through progressive liberalization. Many services, which have long been considered genuine domestic activities, have increasingly become internationally mobile, (e.g. electronic banking, tele-health or tele-education services), the opening up in many countries of long-entrenched monopolies (e.g. voice telephony and postal services). Changes in consumer preferences, such technical and regulatory innovations have also enhanced trade of services and, thus, created a need for multilateral disciplines. ${ }^{30}$

\section{NIGERIA'S MEMBERSHIP AND PARTICIPATION IN THE WTO}

The initial members of the WTO were the parties to the GATT and the European Communities after ratifying the Uruguay Round Agreement. As at 2013, the WTO has 159 members and 25 observers. The subsequent membership of the WTO, have had to negotiate their terms and conditions of membership. Any state or customs territory having full autonomy in the conduct of its trade policies is also eligible to accede to the WTO on terms agreed between it and WTO members. ${ }^{31}$

Nigeria joined the WTO when it came into existence in January $1,1995 .^{32}$ Nigeria is a member of the most active groups in the WTO, such as African, Caribbean and Pacific countries (ACP) ${ }^{33}$ African Group, G90 ${ }^{34} \mathrm{G} 20,{ }^{35} \mathrm{G} 33,{ }^{36}$ Paragraph 6 Countries, ${ }^{37}$ and W52 Sponsors. ${ }^{38}$ These groups, united as they were by a bond

\footnotetext{
${ }^{26}$ Ayodele, A., op cit., p. 109.

${ }^{27}$ WHO, "Trade, Foreign Policy, Diplomacy and health", available at $<$ http://www.who.int/trade/glossary/story091/en/>.Accessed on 17/05/14.

${ }^{28}$ Ladan, M T, op cit, p. 354.

${ }^{29}$ World Trade organization, "GATT and the Goods Council" available at<http://www.wto.org/english/tratop_e/gatt_e/gatt_e.htm>.Accessed on 17/05/14.

${ }^{30}$ WTO, "The General Agreement on Trade in services (GATS) Coverage and Disciplines", available at <http://www.wto.org/english/tratop_e/serv_e/gatsqa_e.htm>. Accessed on 17/05/14.

${ }^{31}$ See Article XII of the WTO Agreements

${ }^{32}$ Osakwe, C., 'WTO Rules will not Impede Nigeria's Agric Sector Development", available at $<$ http://www.thisdaylive.com/articles/osakwe-wto-rules-will-not-impede-nigeria-s-agric-sectordevelopment/146841/>. Accessed on 16/05/14.

${ }^{33}$ African, Caribbean and Pacific countries with preferences in the EU

${ }^{34}$ African Group + ACP + least-developed countries

DOI: 10.9790/0837-2107025665 www.iosrjournals.org


of poverty, economic deprivation and misrule, became the numerical majority in the WTO often speak with one voice $^{39}$ and resort to bloc voting in taking decisions or partaking in deliberations at various fora. They discovered to their great dissatisfaction that the rules governing the WTO in particular and the workings of the international economic system in general, were detrimental to their interest. ${ }^{40}$

In order to counteract the influence of these groups, developed countries have also constituted themselves into the IMEC Group, ${ }^{41}$ the G7 group of industrialised countries of Europe, etc. The other major groupis made up of the countries of Eastern Europe (including Russia), which hinge their major focus on ideological divide that are quite different from the IMEC group. Often, they dissociated themselves with the IMEC group and continuously supported the demands and aspirations of the developing countries for a more equitable international system. ${ }^{42}$

However, as a WTO member state, Nigeria is expected to restructureits trade policies to be in conformity with international standards. Thus, Nigeria, like other developing countries members of the WTO, could neither reject the rules and structures of the WTO, which constitute one of the bases for its state sovereignty and political independence, nor accept absolutely the rules and structures that were detrimental to its interest. Consequently, Nigeria have no options than to accept the existing system and continue to insist that the unfavourable rules and institutional structures be either disregarded or reformulated to take account of its interest, and the realities of the contemporary world and as well call for the creation of new international economic order. ${ }^{43}$

\section{INFLUENCE OF WTO AGREEMENTS ON NIGERIA'S ECONOMY}

Nigeria is a middle income, mixed economy and emerging market, with expanding financial, service, communications technology and entertainment sectors. It is ranked 26th in the world in terms of GDP and is the largest economy in Africa. ${ }^{44}$ It is also on track to become one of the 20 largest economies in the world by the year $2020 .^{45}$ Nigeria's economy has suffered from years of mismanagement, inconsistent and poorly conceived government policies, and the lack of basic infrastructure. In addition, cheap consumer imports, resulting from an overvalued Naira, coupled with excessively high domestic production costs due in part to erratic electricity and fuel supply, have pushed down industrial capacity utilisation. ${ }^{46}$

Although Nigeria must grapple with its decaying infrastructure and a poor regulatory environment, the country possesses many positive attributes for carefully targeted investment and will expand as both a regional and international market player. However, rebuilding and maintaining infrastructure are necessary for the

\footnotetext{
${ }^{35}$ Coalition of developing countries pressing for ambitious reforms of agriculture in developed countries with some flexibility for developing countries (not to be confused with the G-20 group of finance ministers and central bank governors, and its recent summit meetings).

${ }^{36}$ This is a coalition of developing countries pressing for flexibility to undertake limited market opening in agriculture. They are also called "Friends of Special Products" in agriculture.

${ }^{37}$ Group of countries with less than $35 \%$ of non-agricultural products covered by legally bound tariff ceilings. They have agreed to increase their binding coverage substantially, but want to exempt some products.

${ }^{38} \mathrm{~A}$ proposal for modalities in negotiations on geographical indications (the multilateral register for wines and spirits, and extending the higher level of protection beyond wines and spirits) and "disclosure" (patent applicants to disclose the origin of genetic resources and traditional knowledge used in the inventions).

${ }^{39}$ World Trade Organisation, "Nigeria and WTO" available at <http://www.wto.org/english/thewto_e/countries_e/nigeria_e.htm>.Accessed on 17/05/14.

${ }^{40}$ Lifu, P. O., "Conflict and Crises in International Law: Bridging the Gap between Developed and developing

Nations", Vol. 6,University of Ibadan Journal of Private and Business Law, (2011), p. 112.

${ }^{41}$ IMEC; means "Industrialised Market Economy Countries". This includes United States of America, Western

Europe, Canada, Japan and Australia.

${ }^{42}$ Lifu, P. O., op cit., p 115.

${ }^{43}$ Ibid. p. 113.

${ }^{44}$ Waziri, K. M., "Patents Rights, Industrialisation and the Economic Development in Nigeria", Vol.5,Nasarawa State University Law Journal, (2012), p. 82.

${ }^{45}$ Matanmi, S., “Imperatives of Strategic Capacity Building for Nigeria's development Futures: Vision 20/2020 as an Illustration", Vol. 1, Nigerian Journal of Labour and Development Studies, (2012), p. 41.

${ }^{46}$ Global Edge, "Nigeria: Economy", available

at<http://globaledge.msu.edu/countries/nigeria/economy>. Accessed on 14/05/14.

DOI: 10.9790/0837-2107025665 $\quad$ www.iosrjournals.org $\quad 60 \mid$ Page
}


country to attract foreign investment. ${ }^{47}$ Nigeria's trade policy is above all a tool to foster growth for its overall developmental objectives. $^{48}$

For Nigeria, the purpose of joining the WTO are three folds: First, to clearly reaffirm its commitment to the multilateral trading system, its rules and disciplines, and trade liberalisation; second, to emphasise its economic and trade priorities; and third, to restate the challenges that it faces as a developing nation, to seek the concrete and technical support of the international community for fuller and more beneficial integration of its economy into the global trading system. ${ }^{49}$

In discharging its obligations under the WTO agreement, Nigeria has promulgated series of economic policies and programmes for the purposes of facilitating the achievement of rapid economic development and ultimate industrialisation. These policies and programmes included the primary export oriented philosophy; the planned public sector led economic development, import substitution, indigenisation, structural adjustment programme (SAP), deregulation, public private partnership, privatisation and commercialisation, etc. ${ }^{50}$

But, privatisation and commercialisation of public enterprises have been the two key components of economic reforms programme of Nigeria since the mid-1980s. It first came into Nigeria with the introduction of SAP by the Babangida administration in 1986. In spite of popular opposition, lack of tangible result and the patent deficits that have attended the process, it still remains a major preference for public policy planners. It appears that the privatisation exercise in Nigeria has only succeeded in transferring public assets to a few cronies of the powers that be. ${ }^{51}$ For instance, the sale of Transcorp Hotel Abuja to former president OlusegunObasanjo $^{52}$ and most recently the unbundling of Power Holding Company of Nigeria (PHCN) into 18 privatized companies, ${ }^{53}$ etc.

However, the WTO urged Nigeria to simplify its tariff structure and remove import prohibitions as part of efforts to create a sound business environment. ${ }^{54}$ According to the WTO, these restrictions, alongside the increased tariff protection, can distort consumer prices thereby undermining the government's efforts to reduce poverty and increased the incentive for smuggling, with concomitant losses in customs revenue. More so, import bans may affect Nigeria's benefits from its participation in the multilateral trading system. Therefore, liberalization of Nigeria's trade regime, through the simplification of its tariff structure and the removal of import prohibitions, would promote better allocation of resources in line with its comparative advantage. ${ }^{55}$

Nigeria also implemented the National Economic Empowerment Development Strategy (NEEDS) in order to raise the country's standard of living through a variety of reforms, including macroeconomic stability, deregulation, liberalization, privatization, transparency, and accountability. It is expected that the NEEDS would create seven million new jobs, diversify the economy, boost non-energy exports, increase industrial capacity utilisation, and improve agricultural productivity. A related initiative at the state level is the State Economic Empowerment Development Strategy (SEEDS). ${ }^{56}$ It is unlikely whether this policy would yield any fruitful result.

The WTO however, suggested a number of areas where reforms could be beneficial to Nigeria and help strengthen its international trade and investment policies. Such areas include; domestication of WTO agreement in Nigeria to give legal effect to it in local court and reform of multiplicity of other taxes and charges to import,

\footnotetext{
${ }^{47}$ Ibid.

${ }^{48}$ Ogunkola, O., "Nigeria: from Customs Exceptions to a Regional Trade Policy", available at <http://www.interreseaux.org/revue-grain-de-sel/51-special-issue-nigeria/article/nigeria-from-customs-exceptions-

to?lang=fr.>. Accessed on 15/06/14.

${ }^{49}$ See Statement by Rear Admiral JubrilAyinla, op cit.

${ }^{50}$ Alkali, A. H., et al, "A Critical Appraisal of the Legal Regime for the Attraction of Foreign Direct Investment in Nigeria", Vol. 4,Nasarawa State University Law Journal,(2011), p. 189.

${ }^{51}$ Adewumi, F., "Beyond Privatisation: Options for Reform of the Power Sector in Nigeria", Vol. 1, Nigerian journal of Labour and Development Studies,(2012), p.71.

${ }^{52}$ Ayobolu, J., "Fawehinmi and Obasanjo's Ownership of Shares in Transcorp", available at $<q=h t t p: / / w w w . d a w o d u . c o m / a y o b o l u 14 . h t m \& s a=U \& e i=\_r S w U \_n B A o 3 V P N q V g b A K \& v e d=0 C D U Q F j A E \& u s g=A F$ QjCNFTHOoYvMCboOYu6SuWyhHUqS6bjQ>Accessed on 28/06/14.

53 "The Power Holding Privatisation: The Journey So Far", available at $<$ http://www.thisdaylive.com/articles/the-power-sector-privatisation-the-journey-so-far/163271/> Accessed on 28/06/14.

${ }^{54}$ WTO, "Nigeria has Become More Protectionists", available at <http://english.peopledaily.com.cn/200505/12/eng20050512_184634.htm/>. Accessed on 14/05/14. ${ }^{55}$ Ibid.

56 "Economy of Nigeria", available at <http://en.wikipedia.org/wiki/Economy_of_Nigeria> .Accessed on $15 / 05 / 14$
} 
in addition to custom duties; difficult registration procedures and high cost of doing business in Nigeria; large number of draft bills before the National Assembly yet to be passed and burdensome customs procedures and documentation which need to be streamlined. ${ }^{57}$

\section{NIGERIA AND THE REGIONAL ECONOMIC INTEGRATION SYSTEMS}

The periods after the Second World War witnessed the proliferation of regional integrations, ${ }^{58}$ linking together geographicallyand ideologically related states reflecting common interest and sometimes common hostilities.These include; the European Union (EU), the North American Free Trade Agreement, the Association of Southeast Asian Nations(ASAN), the South Asian Association for Regional Cooperation, the Common Market of the South (MERCOSUR), the Australia-New Zealand Closer Economic Relations Agreement, African Union (AU), African Economic Community (AEC), Economic Community of West African States (ECOWAS), etc. ${ }^{59}$

The objectives relates to the integration of the regional trade agreements (RTAs) into the WTO system and how to ingrain within the WTO the solutions those agreements may bring to the new measures to trade in goods and services and seek ways to adopt them. ${ }^{60}$ In order for regional economic integration to be effective, state parties must give up some part of their national sovereignty, empower regional institutions to make binding decisions and implement them. Member states must also adopt and implement measures that would remove all constraints to intraregional trade and investment and adopt measures that are conducive to trade and investment. ${ }^{61}$ Although the UN Charter recognises the legitimate existence of regional organisations, it equally establishes the paramountcy of UN Charter obligations over all other obligations in the event of any conflict. ${ }^{62}$

Nigeria is the linchpin of the ECOWAS with over $50 \%$ of the ECOWAS population living therein. Nigeria's GDP is larger than that of the combined GDP of all the other ECOWAS states put together ${ }^{63}$ Nigeria has made some progress in its implementation of the ECOWAS Common External Tariff by removing some textile items from its list of prohibited imports. It also reduced the number of banned import categories from 44 to 26 items, reduced a number of tariffs, and reiterated its commitment to harmonizing its tariff regime with its neighbors. ${ }^{64}$

Nigeria is a party to so many regional agreements, including the AU and ECOWAS. As the largest economy and market in the African sub-region, it is important for the country to position itself for mutually beneficial trade within and beyond the ECOWAS community. ${ }^{65}$ Nigeria declined signing the Economic Partnership Agreement (EPA) with the EU, though it is an intra-regional process, establishing a Common External Tariff in West Africa as a prerequisite to the signature of the EPA between the EU and ECOWAS. The Nigerian position has had a strong impact on the implementation of the EPA. ${ }^{66}$ In fact, the EPA talks have led to the application of several different tariff regimes in the regionthat are much less advantageous for Nigeria. For instance, non-reciprocal market access applied to "everything but arms" (EBA) for the thirteen LDCs in West

\footnotetext{
${ }^{57}$ Vanguard, Wednesday, 14/04/14, "WTO Applauds Nigeria for Reforms", available at <http://www.vanguardngr.com/2011/07/wto-applauds-nigeria-for-reforms/>.Accessed on 14/04/14.

${ }^{58}$ This is a process in which states enter into regional agreements in order to enhance regional cooperation through regional institutions and rules. See Shaw, M N, (1997), op cit, pp $893-894$.

${ }^{59}$ WTO, "Understanding the WTO: Cross-Cutting and New Issues, Regionalism: Friends or Rivals?", available at<http://www.wto.org/english/thewto_e/whatis_e/tif_e/bey1_e.htm>.Accessed on 15/11/13.

${ }^{60}$ Mendoza, H. B., "Making the WTO a More Effective Tool for Development", Nigeria development and Finance Forum (NDFF), available at

http://www.nigeriadevelopmentandfinanceforum.org/PolicyDialogue/Dialogue.aspx?Edition=57>.Accessed on 15/05/14.

${ }^{61}$ Ladan, M T, op cit, pp $382-383$.

${ }^{62}$ Dakas, C. J., "The United Nations and the Challenge of the New World Order", Vol. 1,Journal of Private and Public Law, University of Jos, (1996), p. 109.See generally Preamble to the UN Charter

${ }^{63}$ Aribisala, F., "ECOWAS Imperative for Nigeria", Nigeria Development and Finance Forum, available at http://www.nigeriadevelopmentandfinanceforum.org/PolicyDialogue/Dialogue.aspx?Edition=63>. Accessed on 14/06/14.

${ }^{64}$ Global Edge, op cit.

${ }^{65}$ Welcome Htspe, "Economic Development and Trade", available at $<$ http://www.htspe.com/economic development and trade.htm>Accessed on 15/04/14. ${ }^{66}$ Ogunkola, O., op cit. 
Africa; the interim EPA regime for two non- LDCs, Côte d'Ivoire and Ghana, that stipulates progressive implementation of a reciprocal free-trade agreement; and ageneralised system of preferences (GSP) regime. ${ }^{67}$

However, regional economic integration in West Africa sub-region is gradually modifying Nigeria's trade policy. Specific measures in the process are the institution of a Common External Tariff (CET), the ECOWAS Agricultural Policy (ECOWAP), and the negotiations of an Economic Partnership Agreement (EPA) between West Africa and the European Union (EU). ${ }^{68}$

It is to be noted that the informal economy of developing countries (Nigeria inclusive) has played a significant role in shaping, functioning and to an extent responsible for the failure of economic integration. It comprises of an economic units and workers that remain outside the world of regulated activities and protected employment relationships, which is so large and significant. But the informal economy of developing countries is so substantial that whatever theory, economic, legal or otherwise that may be propounded, would still prove unworkable as long as this sector is kept out of consideration. ${ }^{69}$

Regional economic integration supports the WTO's multilateral trading system, because it allows group of countries to negotiate rules and commitments that are beyond what is possible at the WTO level. In turn, some of these rules have paved the way for agreement in the WTO. ${ }^{70}$ The WTO agreement recognised that regional arrangements and closer economic integration ${ }^{71}$ would benefits countries. It also recognised that under some circumstances, RTAwould violate the WTO's principle of equal treatment for all trading partners ("mostfavoured-nation principle"). ${ }^{72}$

\section{IMPLEMENTATION CHALLENGES OF THE WTO AGREEMENTS}

The aim of WTO is to promote free trade and stimulate economic growth, but the actions and methods of the WTO evoke strong antipathies, among other things, the WTO is accused of widening the social gap between rich and poor it claims to be fixing. ${ }^{73}$ More than 20 years after the WTO agreements that emerged from the 1986-1994 Uruguay Rounds took effect, Nigeria like any other developing country still experience difficulties with its implementations. ${ }^{74}$ In particular, it faces difficulties in order to put into practice the massive legislative changes required and the little support received from developed countries, despite the special and differential treatment provisions ${ }^{75}$ for developing countries as contained in the WTO agreements to facilitate their integration into the world trading system and to promote theireconomic development. ${ }^{76}$

Nigeriahas never had a decisive role in the WTO system and this may be much more damaging now than ever before, because of three newly emerging features. First, the WTO is increasingly spreading its coverage to new areas. Second, the impact of the WTO agreement (as compared to the GATT) and their operation is much wider and deeper for Nigeria's economy. Third and perhaps the most important, Nigeria's

\footnotetext{
${ }^{67}$ Ibid.

68 Ibid

${ }^{69}$ See Statement by Rear Admiral JubrilAyinla, op cit, p 113.
}

${ }^{70}$ For instance, services, intellectual property,environmental standards, investment and competition policies are issues that were raised at the regional negotiations and later developed into agreements or topics of discussion in the WTO.

${ }^{71}$ RTA may set up a Customs Union of free-trade area that would restrict non-members. See generally Article 24 GATT.

${ }^{72}$ Ladan, M T, op cit, p 383.

${ }^{73}$ Khor, M. "Criticism of the World Trade Organisation", available at <http://en.wikipedia.org/wiki/Criticism_of_the_World_Trade_Organization>. Accessed on 14/05/14.

${ }^{74}$ This covers about 23 specific issues such as market access, balance of payments, trade related investment measures, trade related intellectual property, customs evaluation, safeguards, agriculture and services, etc.

${ }^{75}$ The two broad categories of special and differential treatment provisions are: (1) More flexible terms within specified time limit; for instance, longer transition period, smaller commitment (for example, the commitment on agriculture), and (2) clauses which says in broad terms that developed countries should help developing countries in specific areas (such as technology transfer under intellectual property protection) but without defining exactly what action is needed.

${ }^{76}$ Correa, C. Review of the TRIPS Agreement: Fostering the Transfer of technology to Developing Countries', availalable at <http://www.twnside.org.sg/title/foster.htm> Accessed on 15/12/13.

DOI: 10.9790/0837-2107025665 $\quad$ www.iosrjournals.org $63 \mid$ Page


economy is much more vulnerable at present than before because of its weakness and also exposure to the uncertain external environment. ${ }^{77}$

Developing countries (including Nigeria) have raised implementation issues as a means of addressing perceived inadequacies and inequities in the WTO agreements, including the timeframes in which they have to implement the agreements into national laws. In other cases, implementation problems are linked to severe financial and institutional capacity constraints. ${ }^{78}$ For instance, except for India and South Africa, no developing country has ever issued a compulsory license ${ }^{79}$ for any product, despite their socio-economic, political and public health challenges. This is because there must be an existing company that has the ability and the will to take up the production of substituted products within the country for it to be able to grant a compulsory licence. ${ }^{80}$

Nigeria along with other developing countries have questioned certain aspects relating to the implementation of the TRIPS Agreement, namely the continuous use of unilateral pressures and the lack of actual implementation of Article $66.2^{81}$ and Article $67 .{ }^{82}$ In this context, Egypt, India and the African Group noted that no concrete steps have been demonstrated by developed countries with regard to the fulfillment of their obligations ${ }^{83}$ under the WTO agreement.

However, with globalisation, much emphasis is placed on the economic interest of transnational corporations, while social, cultural and environmental interest and the interest of developing countries are not sufficiently taken into account. Often, developing countries hold economic globalisation responsible for the poverty, hunger, environmental disasters, unemployment and many other wrongs of today's world. ${ }^{84}$ As noted by African leaders:

The unfortunate economic environment confronting Africa particularly mass poverty and crushing foreign debt burden, collapse of commodity trade, inadequate transfer of appropriate and environmentally sound technology, the reverse flow of financial resources, backward scientific and technological capabilities have all led to severe constraints on the continent's development capabilities. ${ }^{85}$

\section{OBSERVATIONS AND RECOMMENDATIONS}

It has been observed that the challenges confronting Nigeria in its bid to comply with the WTO agreements are multi-dimensional and cover policy, legal and economic terrains. In the area of policy making for example, the challenges range from bad government policies to lack of political will. It is the recommendation of this paper that government policies should address issues of national importance. In particular, government should provide an enabling legal, institutional and environmental framework for technological advancement that will encourage FDI, if Nigeria is to be one the 20 largest economies in the world by the year 2020 .

It is the observation of this paper that it is impossible to negotiate effectively with the mechanisms (green room meetings) developed to reduce the number of countries actively participating in deliberations so as to allow the WTO to come to decisions as this would be detrimental to the interest of some members. This paper also recommends that green room meetings should as a matter of course be discouraged in its entirety so as to allow member states the opportunity to be part of every deliberation in the WTO.

It is the observation of this paper that Nigeria's trade policy is characterised by unpredictability, lack of transparency and the confusion created by different regimes. Tariff schedules and lists of banned imports are

\footnotetext{
${ }^{77}$ Bhargirath, L. D., op cit.

${ }^{78}$ WTO, “Implementation Issues: Progress Made but some Difficult Issues Remain", available at<http://www.wto.org/english/thewto_e/minist_e/min05_e/brief_e/brief18_e.htm>. Accessed on 22/01/14.

${ }^{79}$ Patent owner is forced to license patented innovation to a third party and obtain an adequate compensation in return. Compulsory licenses carry grave risks to trade and threats of litigation. For example, when South Africa tried to strengthen compulsory licensing in its own legal system, it was sued by a group of 39 pharmaceutical companies. The suit was later dropped on April 18, 2001.

${ }^{80}$ Alsegård, E, "Global pharmaceutical patents after the Doha Declaration- What lies in the future?", available at<http://www.law.ed.ac.uk/ahrc/script-ed/docs/doha.asp>. Accessed on 10/04/13.

${ }^{81}$ It deals with Incentives for the transfer of technology to Least Developed Countries (LDCs).

${ }^{82}$ Technical assistance to developing countries

${ }^{83}$ Correa, C., op cit.

${ }^{84} \mathrm{Ibid}$.

${ }^{85}$ See Paragraph 14 of Preamble, Cairo Common Position on the African Environment and Development Agenda 1991.
}

DOI: 10.9790/0837-2107025665 $\quad$ www.iosrjournals.org $\quad 64 \mid$ Page


revised frequently. The paper recommends that there should be consistency and continuity in Nigeria's economic policies.

It is also observed that much still has to be done by Nigeria in order to come to terms with the WTO agreement. In this context, privatization and commercialisation which has proved unworkable and yet remains the fashion should be reviewed. It exercise in Nigeria has only succeeded in transferring public assets to a few cronies of the powers that be.

It is the observation of this paper that Nigeria has implemented so many conflicting and inconsistent economic policy options (which sometimes overlap one another) that failed to spur itsdevelopmental objectives. It is therefore the recommendation of this paper that policy makers should endeavour toharmonise these policies for the overall interest of country.

The paper also observes that Nigeria's economy is informal and is outside regulated activities; as such integration of its economyinto global economy is a matter of serious concern. It is also recommended that the WTO would need to address the informal nature of Nigeria's economy with a view to seeing how far it can be integrated into the global economy, in particular, assist in the exploration and exploitation of its untapped natural resources.

It is observed that political instability, corruption, lack of adequate legislation that would encourage FDI and lack of political willto create an enabling environment that will foster technology transfer;etc has characterised Nigeria's polity. This paper also recommends that given the nature and complexity of the process of transfer and acquisition of technology, Nigeria's agitations and circumstances may need to be addressed in the framework of several WTO agreements. Otherwise, it would forever remain technology importing nation.

It is further observed that despite the provisions of the TRIPs Agreement to provide incentives to developing countries (Nigeria inclusive) for the transfer of technology by developed countries, developing countries are still technology importing countries.It is further recommended that the WTO should insist on full implementation of its agreements by member states and countries that are in violation of any obligation should be held accountable. In particular, Nigeria should invoke the violation complaint mechanism against developed countries for failing to discharge their obligations as contained in the TRIPs Agreement for providing incentives for technology transfer.

\section{CONCLUSION}

It is submitted that the WTO is a highly protected system, designed to ensure that Multinational Corporations monopolise the international economic system, with the Bretton Woods institutions as taxcollectors. There is nothing liberal about it. Therefore, from humanitarian point of view, state practice and participation in the WTO and its impacts on Nigeria presents a paradox. Nevertheless, it is neither inherently bad nor inherently good, but like all other tools, it must be utilised wisely, as this would yield positive economic development for the country. While developed countries are insisting on strict compliance of the WTO Agreements, Nigeria and other developing countries are agitating for narrower compliance or reformulation of the entire agreements to suits their socio-economic circumstances, so as to enable them participate equitably. 